\title{
USIA Initiatives for North American Trilateral Exchanges
}

\section{By Marianne Craven}

Marianne Craven is senior academic exchange officer in USIA's Office of Academic Programs.

Qince 1992, The United States Information Agency, an $\mathcal{W}$ independent federal agency whose mission includes promotion of mutual understanding through exchangesand cultural programs, has supported North American higher education cooperation among Canada, Mexico, and the United States. Activities have included funding for university linkages and Fulbright programs, establishment and coordination of an ongoing task force and working groups in the three countries, and creation of an Intemet listserv on North American exchanges. Instructions for subscribing to the listserv are provided at the end of this article.

The initiative began with a conference at the Wingspread Center in Wisconsin, where a task force of distinguished citizens of the three countries was established to plan and develop trilateral activities. In September 1993, a second symposium was held in Vancouver, Canada, where working groups were established to study and develop projects in such areas as electronic information, student exchanges and training, facultypartnerships, enterprise and education, distanceeducation, North American studies, and corporate and foundation activity. A third trilateral symposium is planned for Guadalajara, Mexico, April 23-30, 1996.

USIA has funded six university affiliations since 1993 to promote trilateral exchanges. These grants provide up to $\$ \mathbf{1 2 0 , 0 0 0}$ over a three-year period to a U.S. university; working with foreign counterparts, to support travel and per diem costs for faculty and staffexchanges. Eligible fields include the arts, humanities, and social sciences. Grant recipients to date are:

\section{Fiscal Year 1995}

- Georgetown University, the Instituto Technologico Autonomo de Mexico, and Carleton University, Canada, for a project on the forces that drive enviromental change in each country;

\section{Fiscal Year 1994}

- the University ofWisconsin-Madison, the University of Guadalajara,Mexico, and the University of Guelph, Canada for a project on the forces that drive enviromental change in each country;

\section{Fiscal Year 1993}

- The University of Connecticut, the Instituto Technologico Autonomo de Mexico, and the University of Calgary, for a project on public opinion of NAFTA;

- SanDiego State University, Colegiode la Frontera Norte, and the University of Calgary, for a project on curriculum internationalization;

- the University of California at Santa Barbara, the Universidad Nacional Autonoma de Mexico and McGill University/University of Toronto/University of British Columbia, for a project on economic development and environmental protection; and

- Duke University,El Colegio deMexico, and McGill University, for a project to enrich teaching on the environment, labor, and culture in North America.

The listserv on North American exchanges, NAche-net, is administered by the Institute of International Education for usia. To subscribe, send message to:

MAJORDOMO@LISTSERV. IIE. ORG

with the words "subscribenache-net" (without quotes) in the body of the message (and no message in the subject line) followed by your e-mail address and name. The Nache-net coordinatorat the Institute for International Education is Patricia Link (PLink@iie.org); fax: (212) 984-5393.

usia now has a gopher on the Internet, which includes information about Fulbrigbt and other exchange programs, grant awards, and all requests for proposals published by the Bureau of Educational and Cultural Affairs. The address is: WWW.USIA.GOV/USIAHOME/EDUCATIO/HTML 